\title{
Keepers of the Sacred Flame - Patriotism, Politics and the Chinese History Subject Community in Hong Kong
}

*FLORA KAN (Assistant Professor, Faculty of Education, the University of Hong Kong)

EDWARD VICKERS (Lecturer, Institute of Education, University of London)

PAUL MORRIS (President, Hong Kong Institute of Education)

Abstract:

Chinese History (a subject entirely separate and distinct from 'History') has long been the most politically sensitive subject in Hong Kong's school curriculum. Previous studies have analysed the policies of the colonial and postcolonial governments towards this subject. Here, we examine the role played by the Chinese History subject community (comprising teachers, academics and officials in the government's educational bureaucracy), and look at the way in which this has operated as an autonomous interest group. We conclude that the influence of this subject community has been a key factor limiting the extent to which the local educational authorities have been able to develop a coherent policy in relation to history education in general, and the teaching of national history in particular. Specifically, advocates of the maintenance of Chinese History as a separate subject within the school curriculum have been able, by associating themselves with the post-1997 agenda of 'patriotic education', to effectively hoist the local educational bureaucracy with its own petard.

*Corresponding author Tel. +852-2859-2534; fax: +852-2858-5649

Address: Faculty of Education, The University of Hong Kong, Pokfulam, Hong Kong Email address: flfkan@hku.hk 


\section{INTRODUCTION}

Hong Kong’s political transition from British colony (or 'territory') to a Special Administrative Region (SAR) of the People's Republic of China (PRC) has been marked, in the field of education policy, by a movement from a depoliticized school curriculum to one which explicitly espouses Beijing's agenda of state-centred patriotism. In previous studies the present authors have charted this ideological shift, analyzing the ways in which it has manifested itself in changes to the curricula for History, Chinese History and Civic Education. Hitherto, our principal focus has been on the official process of curriculum development, and the political influences that have shaped that process (Vickers, 2005; Vickers, Kan and Morris, 2003; Kan and Vickers 2002; Morris, Kan and Morris, 2000).

In this article, however, we propose to examine more closely the role played in the development of the school curriculum for Chinese History by an autonomous (or pseudo-autonomous) subject community.

Although in the British system, upon which Hong Kong’s system of schooling has largely been modeled, autonomous subject associations have often played a prominent role in curriculum development (as, for example, was the case with the History Association in the debate over National Curriculum History for England), in Hong Kong, subject associations have tended to be either weak or non-existent. In the 
absence of vocal pressure groups representing teachers of particular school subjects, the process of developing curricula for these subjects has tended to be overwhelmingly dominated by the officials of the Education and Manpower Bureau (EMB, or before 2002 the Education Department [ED]) and especially the Curriculum Development Institute (the CDI) and the Hong Kong Examinations Authority (since 2001 the Hong Kong Examinations and Assessment Authority, HKEAA). The outstanding exception in this regard have been those associated with the school subject of Chinese History, who since at least the mid-1970s have formed a relatively cohesive subject community, even though formal subject associations were only established in 1999-2000.

The term "subject community" is here taken to refer to individuals and groups variously associated with the same school subject, who work together to safeguard the status of that subject and their own interests as stakeholders. This community usually consists of government officials, academics, teachers, and textbook writers who operate either as insiders (for example, as curriculum developers) or outsiders (for example, as a pressure group) in influencing policy making with respect to their subject. Members of the subject community may either organize themselves collectively to protect or promote their subject, or may work as individuals voicing their opinions through the media.

According to Bucher and Strauss (1976), the interests that the subject community 
strives to protect typically include curricular 'territory' (in the form of space in school timetables), resources, recruitment and training. Some scholars also point out that subject communities are seldom homogeneous groupings. Frequently, patterns of curriculum development reflect a power struggle between rival members of the subject community. For example, Goodson (1987) asserts that:

The subject community [in the UK] should not be viewed as a homogeneous group whose members share similar values and definition of role, common interests and identity. Rather the subject community could be seen as comprising a range of conflicting groups, segments or factions. (pp. 26-27)

Ball (1985) holds a similar view:

There are power struggles between groups, coalitions, and segments within the subject community each with their own 'sense of mission' and differing competing vested interests, resources and influences. (pp. 17-18)

In the UK, teachers are recognized as a professional group with a set of professional codes governing its membership. This professional community is thus able to define the "knowledge" that is considered of most worth to be taught in schools. As Esland and Dale (1973) point out:

Teachers, as spokesmen for subject communities, are involved in an elaborate organisation of knowledge. The community has a history, and through it, a body of respected knowledge. It has rules for recognising "unwelcome” or "spurious" matter, and ways of avoiding cognitive contamination. It will have a philosophy and a set of authorities, all of which give strong legitimation to the activities which are acceptable to the community. Some members are accredited with the power to make "official statements" - for instance, editors of journals, presidents, chief examiners and inspectors. These are important as "significant others" who 
provide models to new or wavering members of appropriate belief and conduct. (pp. 70-71)

Where, as in the UK, all teachers go through a process of formal professional training, usually (though not always) in the subject they will go on to teach in school, the experience of training also plays a role in initiating the new teacher into the practices and beliefs of his or her fellow-teachers.

In the case of Hong Kong, however, it is still the case that anyone who possesses a university degree can become a teacher, so long as they register with and obtain approval from the EMB. ${ }^{1}$ This helps to explain why teachers in Hong Kong tend not to be fully recognised as professionals (in the sense that lawyers or doctors are) as they are not required to have a minimum level of professional preparation nor become members of statutory professional bodies (Morris, 2004). The relatively low status of teachers has been a common phenomenon in former British colonies, where education for the "natives" has tended to be under-resourced by the colonial authorities, and where teachers in most schools have typically been regarded as technicians charged with delivering a dry curriculum whose content is determined by high-stakes examinations. While the designation "colonial” is deeply problematic as a description of Hong Kong during the last quarter-century of British rule, the structural and cultural legacy of colonialism has undeniably cast a long shadow over certain aspects of the education 
system - though, as will become evident below, its influence has often been manifested in unexpected ways.

If the status and influence of schoolteachers in Hong Kong has tended to be low, that of the educational bureaucracy, and in particular the subject officers of the EMB and the HKEAA ${ }^{2}$, has been rather high, and bolstered by the security of tenure that officials in these posts have generally enjoyed. The stable nature of officialdom reinforced the bureaucratic attitude of an avoidance of risk. This bears a direct relationship to the relatively small scale of changes made in the Chinese History curriculum in the last half century. At Sixth-form level, the setting of syllabuses for the 'Higher' ('H’ level') (in 1991 replaced by the AS-level) and the Advanced-level examinations provided spheres of influence for academics from the History Department of the Chinese University of Hong Kong and the Chinese Department of the University of Hong Kong respectively. The content of the Higher-level and Advanced-level syllabuses was directly linked with the area of expertise of the staff of the two universities (Kan, 2002, p. 257).

The bureaucratic culture, the power of academics in the Sixth Form subject committees, and the centralized top-down decision-making process (Morris 1995, McClelland 1991) have reinforced the power of subject officers and longstanding members of curriculum committees (in the case of Chinese History, senior academics 
who enjoyed hierarchical superiority over other committee members by virtue of the teacher-student relationship), and hence their ability to define "official knowledge" within the Chinese History subject. Their role corresponds to that depicted by Young (1971):

Those in positions of power will attempt to define what is to be taken as knowledge, how accessible to different groups any knowledge is, and what are the accepted relationships between different knowledge areas, and between those who have access to them and make them available (p. 52).

Notwithstanding the relatively low status of schoolteachers in Hong Kong, there are several teachers' associations operating which aim to enhance the teaching and learning of a specific subject or group of subjects. These include groups such as the Science and Maths Education Association and the Economics Education Association. In the case of Chinese History, it was not until 2000 that two formal teacher associations were set up in response to perceived threats to the interests of the subject. Prior to that, there were no organized efforts made to advance those interests, although various influential individuals in the Chinese History subject community occasionally made their voices heard through the media.

Before discussing the role of this subject community, however, a word is necessary regarding the rather peculiar history of the Chinese History subject itself. The school curriculum in Hong Kong features not one but two entirely distinct history subjects, since in addition to Chinese History there is a separate 'History' subject 
encompassing not only 'World History', but also modern Chinese history and the history of Hong Kong. This is thus not simply a division between national and foreign history, of a kind found in the school curricula of many countries. Rather, it owes its origins to the bilingual nature of the schooling system in colonial Hong Kong, and the influence of a deeply-rooted indigenous historiographical tradition which the British authorities felt obliged to recognise and incorporate within the school curriculum. Prior to the 1950s, Chinese History was taught in Hong Kong using textbooks produced in Nationalist China, but following the Communist victory in the Civil War, and the divisive ramifications of this for Hong Kong (with different groups there supporting the Communists and defeated Nationalists), the government deemed it prudent to domesticate and depoliticise the curriculum for the subject. Curriculum development was effectively delegated to a group of highly traditionalist exiled scholars and teachers (some associated with New Asia College, the kernel of the future Chinese University of Hong Kong), and the result was a curriculum culturally conservative, highly moralistic and glorifying in China's ancient heritage, but devoid of any modern content and politically neutered. The History subject, meanwhile, was taught in English and, until the late 1960s, featured sections focusing on British and Imperial history. After about 1970, however, British content was dropped, and the subject adopted an increasingly modern and contemporary focus. While most schools made the study of both History 
and Chinese History compulsory up to the end of the junior secondary years (roughly age 14-15), from the 1980s onwards the two subjects increasingly found themselves in direct competition for curriculum space at both junior and senior levels. The pressure was most keenly felt by those involved with the History subject, and this helped to spur curriculum developers to look for new ways of maximising their subject's appeal and relevance - a search which ultimately led to the introduction of local history into the curriculum in the 1990s. (See Vickers, 2005; Vickers, Kan and Morris, 2003).

Over the past 50 years, there have been constant disputes within the subject community as well as between the subject community and the colonial government over aims, content and methods of assessment. During the period of British administration, any changes proposed to the curriculum for this subject tended to elicit knee-jerk accusations regarding colonialist plots to suppress nationalism and cultural identity and /or to prejudice the population against the KMT (Kuo Min Tang [Nationalist]), the CCP (Chinese Communist Party) or both. Those who expressed their views in the newspapers included academics, schoolteachers and textbook writers. They did not organize themselves into teachers' associations but acted as individuals, voicing their opinions in a variety of newspapers of various political hues (both proand anti-Beijing, or Taipei). Despite their apparently uncoordinated nature, the public disputes that occasionally erupted over Chinese History did place considerable pressure 
on the colonial government, in particular because of the attention that adverse coverage tended to attract on the Chinese mainland.

Since 1997, changes made to the Chinese History curriculum have not only provoked more furious disputes, for example, allegations that the curriculum revision proposals reflect a neocolonialist plot, but have also prompted more concerted efforts on the part of the Chinese History subject community to organize itself. In the present article, we will first examine the evolving socio-political context of Hong Kong which forms the backdrop to the development of the subject and the evolution of the associated subject community. We emphasise that Hong Kong's Chinese History subject community differs significantly from models derived from UK studies, which see such communities as typically driven by internal rivalry and power struggles. Rather, it has been animated by a firm common belief amongst members of the community regarding Chinese History's central mission of moral and political socialisation. We further argue that the reason why key stakeholders have been able to exert enormous influence over the subject while at the same time seldom being held accountable to any external authority relates to the peculiar political conditions prevailing during the period of British rule and the subsequent transition to Chinese sovereignty. The government's own lack of political legitimacy effectively shielded this group of people - most notably bureaucrats and academics - from public scrutiny 
and accountability. Our discussion is divided into three periods, corresponding to shifts in the wider political context and in the role assumed by the Chinese History subject community: the 1950 s to $1974,1974-1997$ and 1997-2005.

\section{GUARDIAN OF CHINESE CULTURE: 1950s -1974}

In this period, the Chinese History subject community's primary role as a guardian of Chinese culture was closely related to the colonial government's direct intervention in education in general and in the area of Chinese Studies in particular. This intervention was aimed primarily at eliminating from the school curriculum any discussion of China's contemporary politics. We will first discuss the ways in which the colonial government tightened its control of education and Chinese Studies and will follow with an analysis of how the Chinese History subject community assumed its role in response to the socio-political conditions of the time.

After the Communist regime was established in China in 1949, the colonial government, in an attempt to avoid getting drawn into the struggle between the KMT and the CCP, depoliticised the school curriculum and tightened its control of education.

The Government's control over subject curricula, and in particular the history curriculum was recorded in the 1952 Annual Report:

History textbooks present the greatest and most urgent problem. Not only are nearly all existing Chinese texts [i.e. those issued by publishers associated with the Communist or Nationalist parties] unsatisfactory for educational and sometimes for political reasons ... A further difficulty arises from the 
predominance of Chinese history, and the neglect of the history of the rest of the world, in the history syllabuses followed hitherto by nearly all Chinese schools. It is hoped that it will be possible for all secondary schools to follow a course of general world history in which the history of China will be given its due part, together with a supplementary course of the social and cultural history of the kind often given in the present Chinese literature and history lessons. (Annual Report, Education Department, 1952, p.56)

Also in 1952, a Chinese Studies Committee was set up with the purpose of reviewing the aims of and setting the parameters for the future development of Chinese subjects, including Chinese History. It is worth noting here that members of the Chinese Studies Committee were mostly from the education sector and they considered the aim of teaching Chinese history as

... to get rid of this [inferiority] complex by reviving what is good in Chinese culture, thereby instilling fresh confidence into, and restoring the self-respect of her people. This, however, must not be identified with the promotion of vanity and anti-foreignism which is to be strongly deprecated. (Report of the Chinese Studies Committee, p.16)

The committee further suggested that it would be inappropriate to include modern history in the curriculum of Anglo-Chinese Schools and Chinese Middle Schools: ... the two sections, one on Modern Chinese History (A.D. 1644 -1945) and one on Modern World History (A.D. 1789 to present), both sections are predominantly political, and so not quite in line with the general principles which, in the opinion of the committee, should govern the study of history. (Ibid., pp. 14-15)

Following these recommendations, Chinese History curriculum developers changed the scope of study of the 1958 syllabus from A.D. 1644 (establishment of the 
Qing dynasty) - 1945 (end of the Chinese civil war) to A.D. 960 (Song dynasty) - 1911

(end of the Qing dynasty). The 1966 and 1967 riots in Hong Kong and their close connections with the Cultural Revolution in China reinforced curriculum developers' determination to ensure that students did not study the Civil War (1945-49) or the early history of the PRC. Meanwhile, Hong Kong history was excluded from the curriculum. The primary focus was instead placed on the history of the Sui, Tang, Song, Yuan and Ming dynasties (A.D. 581-1643), which have been regarded by Chinese historians as the golden periods of Chinese cultural and imperial history. Chinese History was thus characterized by a process of depoliticization and decontextualization; its content bearing no relation to the contemporary mainland or local context.

In the 1950s and 1960s, the colonial government's programme for depoliticising and decontextualising the school curriculum matched the interests of key players in the Chinese History subject community, in particular textbook writers and academics. For example, H.L. Law, F.L. Wong, T.S Pong, and K.T. Sun had all fled to Hong Kong after the Communist takeover in China in 1949. They were pro-KMT figures whose expertise was in ancient and medieval Chinese history, and as such they were sympathetic to a curriculum that de-emphasised contemporary history and excluded Hong Kong history. They regarded the teaching of Chinese History as a means of transplanting classical Chinese culture from the mainland to Hong Kong, thereby 
nurturing a Chinese cultural identity. During the postwar period, both pro-KMT and pro-CCP members of the subject community deployed anti-colonial rhetoric as an instrument for promoting their respective interests. Pro-KMT members pressed for the establishment of a Chinese cultural identity (as the KMT was then doing in Taiwan) in order to maintain students' sense of Chinese identity under British colonial rule; pro-CCP elements, meanwhile, strove to make sure that the Communist Party and the PRC were portrayed in a positive light, rather than being subjected to denigration by “imperialist” forces. At the same time, the principal curriculum developers considered that a thorough understanding of Chinese history required the teaching of the orthodox state-centred narrative chronologically and in its entirety, from the Xia dynasty (2100 B.C.) to 1911 (end of the Qing dynasty). Their views were expressed in the following minutes:

(i) The study of Chinese History requires considerable understanding and knowledge and the syllabus cannot be reduced. Besides, Chinese History should be studied with a sense of continuity and is quite different from European History, which can be studied as separate units. (ii) Chinese History as an independent subject in the HKCEE (which is not the usual practice in major countries) should be made as dignified as possible (iii) candidates will not be able to finish answering both conventional and multiple choice type questions if the time is reduced in the examination. (Minutes of meeting, Chinese History subject committee [Certificate of Education Examination (CEE)], 5 January, 1970)

As a result, the curriculum involved exhaustive chronological coverage of the entire sweep of Chinese history, dynasty by dynasty, with assessments of the political and 
cultural contribution of each to the greater glory of the Chinese nation. The intention was to promote students' identification with an ancient cultural China, rather than with a modern Chinese state - whether Communist or Nationalist.

Overall, during this period the Chinese History subject community was not an organized entity. Key curriculum developers were scholars exiled from the mainland and others who had grown up locally, most of whom taught in universities and schools. They influenced the Chinese History curriculum through writing textbooks, teaching, and participating in official curriculum committees. The way they defined Chinese historical knowledge and the subject's mission coincided with the colonial administration's goal of rendering the curriculum depoliticised and divorced from both the Hong Kong and contemporary Chinese contexts.

\section{GUARDIAN OF THE “CHINESE HISTORY SYSTEM”: 1974-97}

From 1974 until the end of British rule in 1997, the Chinese History subject community continued to function as a loose association of individuals, rather than a formally organised group. Scholars, teachers and officials continued to express their views in the media, in particular in local newspapers. In this period, the focus of curricular aims shifted and curriculum developers assumed a more prominent and entrenched role as guardians of a now-established "Chinese History system”. Here the “Chinese History system” is taken to refer to the vision of Chinese History as an 
indivisible whole, sacred and inviolable, that must be studied in its entirety to enable students to comprehend the cultural essence of China. This view had been influential during the first period (1950s - 74) but was further consolidated and reaffirmed in the mid-1970s, and persisted more or less unchallenged down to the end of British rule. On the basis of this principle, the subject community strove to maintain the existing curriculum in order to avoid any "contamination" of the subject that might threaten its independent status. Meanwhile, the role played by the subject community, and the way in which officials dealt with the Chinese History subject and its supporters, were closely related to the developing political context, which was characterised by a persistent weakness in the legitimacy of the British colonial administration, and later, in the run-up to Hong Kong’s retrocession, by pressures to realign the education system towards the promotion of a more politicised form of "patriotism" involving identification with the People’s Republic of China.

Compared with the previous period, the years from 1974 to 1997 witnessed relative political stability as émigrés from China in the early 1950s had settled down and a new generation born and brought up in Hong Kong had come to regard it as their homeland. Thus a stronger local identity began to take root. The colonial government was conscious of its low level of legitimacy, and therefore as long as serious political embarrassment for the government could be avoided, and in particular threats to its 
relationship with the PRC minimised, the administration tended not to interfere with the activities of entrenched vested interest groups. As economic development proceeded and a middle class began to emerge, the government embarked on a large expansion of educational provision. Secondary schools in the 1970s increasingly needed to cater for a mass student clientele, rather than the narrower elite of previous decades, and therefore calls for curricular reforms arose, particularly among some government officials and university academics.

In 1975, the government announced that it was to recommend the integration of Economic and Public Affairs, Geography, History, and Chinese History to form a new subject, Social Studies. This proposal was regarded by its advocates as an enlightened and progressive measure, and was inspired by similar "progressive” curricular innovations in the United States and elsewhere. However, the idea was greeted with outrage amongst the supporters of the Chinese History subject. The government was accused of trying to weaken Chinese "national sentiments" by integrating Chinese History into Social Studies instead of maintaining its independence. On 7 March 1975, the Chinese-language Oriental Daily newspaper devoted its entire front page to reports of protests against the colonial government's intentions. Key curriculum developers such as university professors and union leaders expressed views such as the following: [This is a] conspiracy of the coloniser to carry out colonial education: this integration will weaken students' Chinese awareness and national conception. 
Social Studies aims to enhance students' sense of belonging to Hong Kong, and this action is in itself incorrect. Being Hong Kong Chinese we should not only have Hong Kong in our mind. (K.T. Sun, Professor, Chinese University of Hong Kong and Chinese History textbook writer, 7 March 1975, Oriental Daily)

The integration will add to the burden on teachers and students, [and] this is another form of colonial education. In weakening students' knowledge of and sentimental attachment to China, the government aims to transform Chinese into Hongkongese.' (Szeto Wah, Chairman, Professional Teachers Union, Ibid)

The outcome of the dispute was that although the Social Studies subject was introduced, it was made optional (most schools did not choose to adopt it), and Chinese History was not included in the curriculum, and thus retained its total independence. More importantly, in 1975 the Curriculum Development Council (CDC) recommended that Chinese History become one of the subjects comprising the common-core curriculum ${ }^{3}$. The subject community's strong antipathy towards the integration of Chinese History into Social Studies sent a message to the government: any attempt to reform the Chinese History curriculum could provoke vocal dissent, and in particular arouse nationalist and anti-colonial resentment.

Thereafter, members of the subject community made use of a variety of channels to air their views. In the 1970s and 1980s, whenever Sino-Japanese disputes arose, for example over the sovereignty of Diaoyutai/Senkaku Islands, or the Nanjing Massacre, or narratives of the Pacific War in Japanese history textbooks, members of the subject community would routinely use these occasions to call for a strengthening of Chinese 
History education and the cultivation of nationalism as a means of instilling in students a sense of the importance of national strength and solidarity in the face of (perceived) Japanese imperialism.. After the signing of the Sino-British Joint Declaration in 1984, it was also proposed that the scope of study should be extended to cover contemporary history, and that the role of Chinese in patriotic education should be strengthened. As we shall see, in the run-up to and following the 1997 retrocession, the advocates of Chinese History did indeed increasingly seek to define their subject's role as the standard bearer of patriotic education.

After the 1975 Social Studies fiasco, changes made to the Chinese History curriculum were minimal. The subject was henceforth defined as a sacred and inviolable realm within the school curriculum, and having repulsed the assault of the Social Studies reformists, Chinese History teachers and their supporters retreated once more into the impregnable fortress of "tradition". Following their success in maintaining Chinese History’s independent status, curriculum developers issued a teaching syllabus for junior secondary Chinese History that aimed to encourage an identification with what was portrayed as an indivisible, immemorial and essentially unchanging indigenous culture:

Chinese culture has a long history. ... In five thousand years, the Chinese nation has produced great achievements in intellectual thinking and technology. Moreover, there are special characteristics in the way of life and social organization of the Chinese nation. Hence the first most important aim of teaching 
Chinese History is to guide students to appreciate the long-existing Chinese cultural tradition and the characteristics of the way of life of the people. (Chinese History syllabus, S1-3, ED, 1975, p. 3)

This syllabus marked the consolidation of the established "Chinese History system”, and a similar statement of aims was included in the S4 -5 syllabus. The 1975 syllabus extended the period of study from the Xia dynasty (2100 B.C.) to 1949. With the continuing exception of contemporary history, the entirety of Chinese history had to be studied, and the same applied to the syllabuses for S4-5 and S6-7. In other words, as during the previous period, Chinese History content was depoliticised and characterized by a focus on imperial deeds and personages (and the 'correct' apportionment of praise and blame in relation to such figures), as well as on cultural history.

Notwithstanding the increasing strength of a distinctive local sense of identity during the 1970s and thereafter, the cultivation of local sentiment was never viewed as a legitimate or desirable aspiration on the part of the Chinese History subject community. For them, pan-Chinese nationalism was incomparably more important than what they saw as at best an ephemeral, or at worst a "mongrel" sense of local identity. Thus local history remained beyond the pale of Chinese History curricula throughout both the first and second periods discussed here. As a key Chinese History subject officer remarked: 
We have to learn Chinese History. Each dynasty has its own characteristics. Students should, as far as possible, learn these characteristics before they can come to appreciate the greatness of China. Given that time is insufficient to study Chinese History, how could we include Hong Kong history in the curriculum?. (Interview, 4 August 1999)

There were major revisions to the curricula for most school subjects in the 1980s and 1990s, including the History subject. Many of these reforms - or proposals for reform - resulted from concerns prompted by the shift from an elite towards a mass system of secondary education, and by social, cultural and political changes affecting Hong Kong more broadly. In the case of History, this period witnessed the introduction of data-based-questions, an increased emphasis on contemporary history, growing concerns over the use of English as a medium of instruction, and moves to introduce local history into the curriculum. However, Chinese History was effectively insulated from such broader trends. While this can largely be attributed simply to the extreme conservatism of the subject community, the nature of the bureaucratic system under British rule also played a part in protecting the subject's key curriculum developers from pressure to change. According to the Head of the History Section:

Although not all officers worked for money, the restrictions and bureaucratic culture obviously hindered the motivation of staff. Every now and then, feature articles relating to Chinese History appeared in the newspapers. The issues related to textbooks, examinations, and political factors. Once the issues were made known to the public, the senior officers, who were mostly British, would require a full English translation of the coverage of the incident. Under such circumstances, how could we work things through? Therefore, officers would try to avoid being 
caught in any issues. And hence a mentality of 'no work no fault' was common amongst civil servants. (Interview, 9 August 1999)

This view was echoed by the key Chinese History subject officer “... In a bureaucratic organization, one would not expect any great reward [for exercising initiative]. The most important thing was not to commit errors ...” (Interview, 4 August 1999). This helps to explain the minimal changes made to the Chinese History curriculum between 1974 and 1997.

In the Chinese History subject committee, members were, in one way or another, associated with the subject officer. In an interview, this official recalled "I came to know these teachers through inspection, and I was sure that we held a common belief about Chinese History. That was why in the meeting never once did we have to vote for a decision. We all had a consensus ...”. (Ibid.) In other words, the unchallenged reign of curricular orthodoxy was ensured in part through the co-opting onto the key committee of teachers who supported it. However, it was not merely the "packing" of the committee that ensured this conservative triumph. The relationships between academics, teachers and officials both within the committee and in the broader subject community outside it involved a web of teacher-student ties characterised by a culture of deference to seniority. During this period, the colonial government (having had its fingers burnt in 1975) adopted a laissez faire approach towards curriculum 
development for Chinese History, leaving decision-making to the representatives of the subject community sitting on the Chinese History committee. Meanwhile, the PRC government by its very existence exerted pressure on the Chinese History subject community, although in a subtle and intangible manner. This was particularly the case after 1984 (the year of the Sino-British Joint Declaration), when Chinese History teachers and curriculum developers became aware that Hong Kong's impending retrocession would present them both with a challenge to conform to the mainland regime's interpretation of the past, and with an opportunity to enhance their status as the flag-bearers for "patriotic" values within the local education system. Under these circumstances, curriculum developers responsible for Chinese History, while striving to retain the existing curriculum and pedagogical style, continually regulated the subject's scope of study in accordance with China's political situation. Their object was to maintain the "Chinese History system" with as little alteration as possible, while protecting the subject from political criticism. The exclusion of post-1949 history from the curriculum until 1990 was largely a consequence of a desire to avoid adopting a potentially controversial position on events such as the Great Leap Forward or the Cultural Revolution, in the absence of any agreed "correct verdicts" on these episodes among official historians on the mainland. According to the key Chinese History subject officer: 
Concerning the proposal for extension of the scope of studies to 1976, the major problem involved setting the marking scheme, in particular regarding the Cultural Revolution, when there were not yet any official views established in China. (Ibid.)

Eventually, however, the end date of the syllabus was extended to 1976 in 1991 after the PRC authorities had adopted a consensus verdict on the Cultural Revolution:

Many historians feel the syllabus can be extended to around 1976 because 'the dust has settled' for the period and reference books on the matter are easily available on the market. (South China Morning Post, 10 July 1989)

Evidently, official interpretations of post-1949 events by the Beijing authorities have had a direct impact on the Chinese History curriculum in Hong Kong. However, the extent of this impact has been due to the collective willingness of members of the subject community to trim their sails to the prevailing winds from Beijing. They have themselves made sure that the curriculum does not provoke Beijing, rather than receiving direct or explicit instructions from the PRC to make amendments to curricular content.

It should be noted that although the scope of the curriculum was in 1991 extended to 1976, this did not necessarily involve any significant politicization of the curriculum, particularly since the discussion of alternative interpretations of historical events was not encouraged. Public examination questions relating to contemporary China were confined to factual narration, for example: “Generally describe the process of the Cultural Revolution from May 1966 to the end of 1968”(1997 CEE); and “Give a 
full narration of the following events: the Great Leap Forward, the Cultural Revolution” (1997 A-level). Since these and other examination questions simply required the regurgitation of textbook narrative, which was itself studiously cautious in its interpretations of all controversial issues, the curriculum remained essentially decontextualized and depoliticized.

A combination of bureaucratic inertia and political timidity (on the part of the colonial authorities) thus contributed to the effective insulation of Chinese History from pressures for change that were influencing other school subjects between the mid-1970s and 1997. Meanwhile, with the passing of time, the ultra-traditionalist orthodoxy enshrined in the curriculum during the 1950s and 1960s was imparted to successive generations of students and teachers as a sacred trust - their mission being to impart this in turn to scions of the Glorious Motherland as yet unborn. Finally, across the border in the Motherland itself, as the regime jettisoned socialism in favour of a revamped nationalism, the ideological position of the formerly hated Communists began to look more and more palatable to Hong Kong's more traditionalist cultural patriots. It was this relationship with the mainland's new nationalism that would shape the fate of Chinese History in the period following the 1997 retrocession.

CHAMPION OF NATIONAL EDUCATION: 1997-2005 
In 1997, Hong Kong became a "Special Administrative Region" (SAR) of the People’s Republic of China (PRC). The main difference between this period and the previous two is that the education reforms of 1999, which had at their core an attempt to integrate school subjects and thereby trim the school curriculum, prompted Chinese History teachers, academics and their supporters to organize themselves into two teacher associations to counteract the potential impact of these proposals on Chinese History. In order to enhance its status and protect its curricular territory, the subject community has increasingly sought to link Chinese History education with the programmes for national (or "patriotic”) education through which the post-1997 administration has sought to foster a heightened consciousness of national identity among Hong Kong's population.

Before the handover, curriculum developers had already begun preparations for a revision of the curriculum to meet the requirements of the new political dispensation. The changes made to the S1-3 Chinese History curriculum accurately reflected the priorities and sensitivities of the new SAR government and its Beijing backers. For example, the revised curriculum stressed the importance of arousing national identity through the study of Chinese History, inserting into the curricular guidelines the aim of "cultivating a sense of belonging to the nation and its people” (S1-3 Chinese History syllabus, CDC, 1997, p.8). Secondly, Hong Kong history was for the first time included 
in the syllabus, a measure aimed at "enhancing students' interest in studying this subject, and establishing local and national sentiments” (S1-3 Chinese History syllabus, CDC, 1997, p.8). However, this was largely a symbolic move, since local history was confined to an optional "appendix" to the main course. This contrasted starkly with the treatment of local history in the History subject, where it was integrated as a core component of the curriculum. Indeed, the preparation of the local history "appendix" to the Chinese History syllabus can be seen as a reaction to its introduction into the History curriculum, and a symbolic assertion of Hong Kong’s “Chineseness”. These Chinese History teaching materials portrayed Hong Kong merely as a sideshow to the main drama of the national past, ignoring the recent development of a distinctive local identity, and from the opening paragraphs of the narrative ramming home the message that Hong Kong "has been a part of China since time immemorial”. (CDI, Teaching Materials for Local History, issued as an Appendix to the Junior Secondary Chinese History syllabus, 1997; see also the discussion of this in Vickers, 2005, Chapter 7.)

In the first few years after the handover, the subject community remained as disorganized and ad hoc as it had been in previous periods, with members expressing their views in the media either through broad-based teaching unions or individually. Meanwhile, the Chief Executive, C.H. Tung, in his policy addresses repeatedly called for the promotion of Chinese studies in Hong Kong. In his 1997 inaugural address he 
declared: "We will incorporate the teaching of Chinese values in the school curriculum and provide more opportunities for students to learn about Chinese history and culture. This will foster a stronger sense of Chinese identity in our students” (Policy Address, 8 October 1997). Such statements appeared to indicate strong official backing for the Chinese History subject, and to promise an enhancement of its role and status within the school curriculum.

However, in 1999 the SAR government, apparently feeling that its Beijing-bestowed mandate gave it greater authority and leverage over education policy than its colonial predecessor, announced sweeping educational reforms. The proposals included a recommendation to merge the separate subjects of History and Chinese History to form a subject provisionally called "New History". At the same time, the CDI proposed the introduction of eight “Key Learning Areas” (KLA). Chinese History along with History was included within the KLA of "Personal, Social and Humanities Education” (PSHE).

In the event, this "New History" episode turned out to be just one of many instances since 1997 in which agencies of the SAR government have fallen foul of contradictions bedeviling the administration's agenda. With respect to education, the key contradiction affecting Chinese History has been between the priority accorded to the promotion of "patriotic education" on the one hand, and on the other hand the 
importance attached to fostering "critical thinking” and analytical skills (seen as crucial to Hong Kong’s successful engagement with the global "knowledge economy”). Many of those reformers within and outside the educational bureaucracy who have focused on the latter priority have long aspired to take an axe to Chinese History, which they see as a redoubt of hidebound teaching methods and excessive content, forcing students to memorise dry facts without affording them any opportunities to exercise their own critical judgement. There is little doubt that in 1999, reformers within the ED hoped that a comprehensive shake-up of the entire education system would provide them with an opportunity to instigate an overhaul of history education that would at last begin to undermine the foundations of the Chinese History fortress.

However, predictably enough this proposal provoked a reaction on the part of the subject community similar to that witnessed in 1975 , in response to the proposal to incorporate Chinese History within an integrated Social Studies curriculum. In 1999, Chinese History educators organised themselves into two subject associations: the Hong Kong Teachers’ Association of Chinese History Education (zhong guo li shi jiao yu хиe hui) and the Chinese History Educators’ Society (zhong guo li shi jiao shi hui ). These two teachers' associations presented themselves as pressure groups and in their mission statements specified, in the words of one of them, the need "to take into close concern and respond to [sic] those socio-political events that relate to Chinese history 
education” (Founding ceremony of the Chinese History Educators' Society, 7 July 2000). At the same time, both associations openly sought to wrap themselves in the mantle of patriotic education:

... after the handover, Hong Kong people have to accept their Chinese identity. Our students have to study Chinese history in order to enable them to understand our own past, our own identity and our own role. This understanding can help us to take up the responsibility of being Chinese so that we can do our best to contribute to our nation. As teachers, we do not have to hide our feelings and passion as we did during the colonial period. Chinese History has a special mission: to nurture stuents' national feelings and patriotism .... (P.W. Leung, Chairman, Chinese History Educators’ Society, Ibid.)

Both associations have publicised teachers' concerns in the media and on websites, and pressed key government officials to take a close interest in the subject. When major press editorials took sides with the subject community, the SAR government was placed in an embarrassing situation:

Chinese History should be strengthened not weakened. (Editorial, Ming Pao, 7 April 2000)

Education Department merges the two histories and is bombarded for ignoring national sentiments. (Editorial, Oriental Daily, 8 April 2000)

The Education Department has evil intention in merging the two histories. (Editorial, The Sun, 23 April 2000)

Several weeks later, a top-ranking Beijing official, Chen Zhili, also implicitly allied herself with the subject community:

Chinese History is part of world history but as Chinese, we should learn Chinese History thoroughly. The subject should be introduced to students in a very 
comprehensive and scientific way. There needs to be more academic discussion on whether it should be merged into world history as a small part. (Sunday Morning Post, 28 May 2000)

K.F. Fung, vice-chairman of the Chinese History Educators' Society, in his article The Way Forward for Chinese History points out that in order to solicit support from different parties, the association's tactic is to meet influential key players directly and ask for their support in fighting for an independent Chinese History curriculum. The list has included representatives of the Office of the Chief Executive, HKSAR, the Central Liaison Office (Beijing's headquarters in Hong Kong), the Curriculum Development Institute, and various political parties. (Fung, 2003, p. 160)

In this period, the SAR government and curriculum reformers found themselves under enormous pressure because of the views expressed by senior Beijing officials as well as the strategy adopted by the subject community, which effectively accused the local authorities of betraying the patriotic cause. As a result, "New History” was quietly shelved in 2002 after the completion of a pilot scheme. The political sensitivity surrounding Chinese History, and in particular the government's sensitivity to any accusations of a deficiency of "patriotic" fervour among its officials, meant that it was felt to be necessary to appease the subject community.

Since the handover, the Chinese History subject community has further solidified its power, and has become more organized in defending its role as the standard bearer 
for national education, thus counteracting any curriculum reforms that might threaten either the status or the inviolable essence of the subject. Hence, representatives of the two teacher associations took part in the revision of the S4-5 Chinese History curriculum which was introduced in 2003. This revised curriculum reflected a comprehensive and enthusiastic embrace of "patriotism” as the guiding principle of Chinese History education and was the product of a struggle between the subject community and leading officials within the EMB and HKEAA, testifies to the power wielded by the supporters of the Chinese History subject: whereas the original proposal put forward by the EMB and HKEAA envisaged sweeping changes (including a focus on the modern and contemporary period, and options on the history of Hong Kong and Taiwan), the revised curriculum stressed the inheritance of Chinese culture, expanded the chronological scope of study from the Zhou dynasty ( 1100 BC) to the end of the $20^{\text {th }}$ century, and laid particular emphasis on Chinese History's role in promoting national identity (Chinese History Curriculum and Assessment Guide, S4-5, CDC \& HKEAA, 2003). In general, therefore, it would appear that the subject community had yet again ensured that in Chinese History plus ca change, plus c'est la meme chose, though it should be noted that the new curriculum also includes a nod towards the importance of promoting students' critical thinking skills, and the guidelines devote considerable space to an introduction of the inquiry approach in learning and 
assessment. However, as seen from the sample questions prepared by the HKEAA, inquiry questions and data-based questions were not included. The difference in requirement between this new curriculum and the previous ones was that students were given room to express their views.

\section{CONCLUSION}

The colonial government's impact on the Chinese History curriculum was direct and powerful in the first period, gradually becoming more indirect and nominal in the second period. As long as the boat was sailing peacefully, the colonial government did not subsequently interfere in the curricula for the Chinese cultural subjects. We have previously argued that Hong Kong’s Chinese History curriculum was a product of collaborative colonialism between the Chinese History subject community and the colonial authorities (Vickers, Kan and Morris, 2003). Hunter's (1995) concept of a "local community elite" is relevant here. According to Hunter, the “local community elite” can exert enormous influence on policy making, and wields its power backstage:

The front stage of local community elites are often the very basis and substance of their power, for the power structure is often directly reflected in the steel and glass buildings and impressed in the concrete of the physical development of the local community ... Although the public frontstage may reflect the power of local elites, it is in the backstage where the power itself is most often wielded. The backstages of elites are carefully guarded from public view, and they have the power to protect them. (1995, pp. 153-54) 
Since most of those responsible for the development of the Chinese History curriculum (particularly the senior academics and officials who dominate curriculum committees and vet textbooks), play their role backstage, they are rarely held accountable for Chinese History’s conservative, rote learning-oriented curriculum. On the contrary, students' lack of critical thinking skills and their weak sense of national sentiment have been seen as products of the colonial government's deliberate efforts to nurture a group of submissive and unintelligent students who were detached from their motherland. The media, and those critical of the Chinese History subject within academia, the teaching profession and the educational bureaucracy itself, have seldom expressed their opinions publicly, largely for fear of being branded "unpatriotic" or "colonialist” by supporters of Chinese History.

We have pointed out that this local community elite, when it appeared at "front stage", whether to assume the role of guardian of Chinese culture, defend the "Chinese History system”, or wrap itself in the mantle of "national education”, was not simply following an agenda dictated by the colonial or SAR authorities, but was in one way or another pursuing its own interests and acting according to its own beliefs. In fact, the role of the colonial government in all this was largely restricted to opening up space within the school curriculum for Chinese History teachers and curriculum developers to occupy. Once they were in residence, subsequent attempts on the part of government 
officials to evict them, or even to renegotiate the terms of their tenancy, were successfully rebuffed. Thus we argue that it is primarily because of the dogged territoriality and doctrinaire traditionalism of this subject community that the curriculum for Chinese History has remained largely unchanged for more than 50 years. And this has resulted in a focus on content knowledge centring on imperial court personages and their deeds, and a chronological approach in which the exhaustive study of an orthodox narrative of China's past is deemed essential. That a largely closely related and self-perpetuating elite within the subject community were able to define Chinese History's nature and scope and maintain this status quo for 50 years can be attributed to a culture of deference towards bureaucrats and university academics in the subject committees, and the unwillingness of successive administrations to pursue reform in the face of allegations of neo-colonialism or lack of patriotism.

As a result, a cobwebbed orthodoxy has been successfully defended over the past fifty years, whereby the same curricular content (covered at different levels of detail) has been offered to students at the levels of S1-3, S4-5, and S6-7. A remarkable degree of consensus within the Chinese History subject community over aims and content has underpinned solidarity in defence of Chinese History’s status as an independent school subject, and a "core" component of the school curriculum as a whole. The pattern observed here appears to differ from Goodson's portrayal of subject communities in the 
UK, which he sees as typically characterised by power struggles between rival members of the subject community. In the case of Chinese History, challenges to the authority of senior academics and officials have seldom been witnessed. At the same time, the Chinese History subject community's interference in curriculum policy making has been unique among school subjects in Hong Kong, where the absence of influential intermediate groups, such as teacher associations, in Hong Kong has in general led to a marked weakness of subject communities vis-à-vis the government (Morris (1990) and Vickers (2005)).

\section{NOTES}

1 In 2003 the government plans to set up basic criteria for prospective teachers, such as a university degree plus a teacher's certificate.

2 The HKEA is a quasi-autonomous government organization, responsible for administering public examinations.

3 Peiping was the name given to Beijing by the Nationalist Government, which had made Nanjing the national capital.. The name Beijing was reinstated after the establishment of PRC moved the capital back there in 1949.

4 The common-core subjects include Chinese History, Chinese language, English language, Mathematics, Science, Social Studies, Art and Design, Ethics/Religious Studies, Home Economics/Design and Technology, Physical Education, and Music. 


\section{A comparison of the current two history subjects in Hong Kong (Junior level and CEE)}

\begin{tabular}{|c|c|c|}
\hline Features & History & Chinese History \\
\hline & $\begin{array}{l}1995 \text { Secondary 1-3 } \\
\text { curriculum guide }\end{array}$ & 1997 Secondary 1-3 curriculum guide \\
\hline $\begin{array}{l}\text { Chronological } \\
\text { scope }\end{array}$ & $\begin{array}{l}\text { Ancient period } \sim 3000 \text { BC to } 20^{\text {th }} \\
\text { Century }\end{array}$ & Ancient period $\sim 2100 \mathrm{BC}$ to $1970 \mathrm{~s}$ \\
\hline $\begin{array}{l}\text { Geographical } \\
\text { scope }\end{array}$ & $\begin{array}{l}\text { Ancient and medieval Europe, two } \\
\text { world wars, Hong Kong }\end{array}$ & History of China \\
\hline \multicolumn{3}{|c|}{$\begin{array}{c}2003 \text { Secondary 4-5 curriculum guide } \\
\text { (first examined in 2006) }\end{array}$} \\
\hline $\begin{array}{l}\text { Chronological } \\
\text { scope }\end{array}$ & Focus on the $20^{\text {th }}$ Century & $\begin{array}{l}\sim 1100 \mathrm{BC} \text { (Zhou dynasty) to end of the } 20^{\text {th }} \\
\text { Century, though aiming at 'detailing contemporary } \\
\text { history while de-emphasizing ancient history' }\end{array}$ \\
\hline $\begin{array}{l}\text { Geographical } \\
\text { scope }\end{array}$ & $\begin{array}{ll} & \text { Asia ( HKSAR, China, } \\
& \text { Japan and Southeast Asia) } \\
\text { - } & 20^{\text {th }} \text { Century world (the two } \\
\text { world wars, international } \\
\text { cooperations) }\end{array}$ & History of China \\
\hline View of history & $\begin{array}{l}\text { A critical discipline (at least in } \\
\text { theory). Historical truth is not } \\
\text { absolute - different, equally valid } \\
\text { interpretations are possible. }\end{array}$ & $\begin{array}{l}\text { The official syllabus stipulates 'the development of } \\
\text { students' analytical ability and objective attitude', } \\
\text { but in practice embodies a single, orthodox view. }\end{array}$ \\
\hline Moral agenda & $\begin{array}{l}\text { no overtly moralising tone in the } \\
\text { intended curriculum and exam } \\
\text { questions. }\end{array}$ & $\begin{array}{l}\text { - the subject is explicitly seen as a moralising } \\
\text { agent. } \\
\text { teaching good conduct through the study of } \\
\text { certain historical figures is a key aim } \\
\text { at the junior level, a prescribed set of values is } \\
\text { laid down under each topic. }\end{array}$ \\
\hline Role/ function & $\begin{array}{l}\text { Shift over the past two or three } \\
\text { decades : } \\
\text { from simple objective of } \\
\text { understanding the past } \\
\text { to a more complex and } \\
\text { ambitious set of objectives } \\
\text { such as 'critical thinking } \\
\text { skills', 'sceptical' attitude } \\
\text { towards sources, and } \\
\text { 'civic-related' aims geared } \\
\text { towards enabling students' } \\
\text { to exercise their rights as } \\
\text { citizens of an increasingly } \\
\text { liberal, democratic polity. }\end{array}$ & $\begin{array}{l}\text { Considerable differences before and after the } \\
\text { handover of sovereignty in 1997: } \\
\text { - from 'knowing', 'understanding' and } \\
\text { 'analysing' the traditional Chinese culture, } \\
\text { dynastic history, and behavioural modelling } \\
\text { of certain historical figures } \\
\text { to an explicit development of a sense of } \\
\text { belonging to China and 'the Chinese race'. }\end{array}$ \\
\hline
\end{tabular}

\section{REFERENCE}

BALL, S. (1985) Relations, Structures andCconditions in Curriculum Change: a political history of English teaching 1970-85, in: I. GOODSON (Ed) International Perspective in Curriculum History (London, Routledge).

BUCHER, R. and STRAUSS, A. (1976) Profession and Process, in: M. 
HAMMERSLEY and P. WOODS (Eds) The Process of Schooling (London, Routledge and Kegan Paul).

ESLAND, G. \& DALE, R. (1973) School and Society Course E282 unit 2 (Milton Keynes, Open University Press).

FUNG, K. F. (2003) The Way Forward for Chinese History, in: S.C. YEUNG (Ed) History Teaching (Hong Kong, Chunghwabook). [in Chinese]

GOODSON, I. (1987) School Subjects and Curriculum Change (London, Falmer Press).

HUNTER, A. (1995) Local Knowledge and Local Power: notes on the ethnography of local community elites, in: R. HERTZ and J. IMBER (Eds) Studying Elites Using Qualitative Methods (London, Sage).

KAN, F. (2002) Chinese History in Hong Kong: the secondary school curriculum, 1946-2001 (Unpublished Ph.D. Thesis, the University of Hong Kong, Hong Kong).

MCCLELLAND, J.A.G. (1991) Curriculum Development in Hong Kong, in: C. MARSH, and P. MORRIS (Eds) Curriculum Development in East Asia (London, The Falmer Press).

MORRIS, P. (1990) Curriculum Development in Hong Kong (Hong Kong, Faculty of Education, The University of Hong Kong).

MORRIS, P. (1995) The Hong Kong School Curriculum - development, issues and policies (Hong Kong, Hong Kong University Press).

MORRIS, P. (2004) Teaching and Teacher Education in Hong Kong: professionalization, accountability and the state, Research Papers in Education, 19(1), pp. 105-121.

MORRIS, P., KAN, F. \& MORRIS, E. (2000) Education, Civic Participation and Identity: continuity and change in Hong Kong, Cambridge Journal of Education, 30, pp.243-262.

YOUNG, M. (1971) Knowledge and Control (London, Collier-Macmillan). 
VICKERS, E. (2000) History as a School Subject in Hong Kong: 1960s -2000 (Unpublished Ph.D. Thesis, the University of Hong Kong, Hong Kong).

VICKERS, E. (2005) In Search of an Identity: the politics of history as a school subject in Hong Kong, 1960s-2005 (Hong Kong, Comparative Education Research Centre, second edition; first edition published in New York by Routledge, 2003).

VICKERS, E., KAN, F. \& MORRIS, P. (2003) Colonialism and the Politics of 'Chinese History' in Hong Kong's schools, Oxford Review of Education, 29, pp. 95-111. 